\title{
Executive Director's Report
}

\author{
Catherine E. Rudder, American Political Science Association
}

This his year, members have shown how deeply they care about the Association's future. Admittedly, when President Robert O. Keohane first suggested that a Strategic Planning Committee (SPC) be formed, no groundswell of enthusiasm could be detected among APSA members. However, as the work of Paul Beck's SPC proceeded, the committee began to hear from increasing numbers of people.

Rather than waiting to produce one large report for member reaction, the SPC has been regularly posting preliminary reports on the web (www.apsanet.org/new/planning) and asking for responses via email, the web, and public sessions held at the regional meetings. Members have neither been shy nor univocal in their reactions, especially in regard to proposals concerning $A P S R$ and, to a lesser extent, the Association's mission statement. The committee has tried to balance diverse opinions and to develop a vision that will carry APSA forward over the next decade and will submit its initial final draft recommendations to the Council in time for discussion at its meeting during the Annual Meeting. Members will have ample opportunity to respond to the full report before official action is taken at the spring 2001 Council meeting.

Some might ask why, at a time when the Association has strong programs, robust investments, thriving Organized Sections, and balanced budgets (Tables 1-3), a planning process is necessary. After all, no crisis looms. There are several answers. In 1998, the staff conducted a survey of current and lapsed members that indicated the need to review APSA publications and programs. PS: Political Science and Politics and the Annual Meeting were found to be popular among members and nonmembers alike. That almost half of the membership attends the meeting each year attests to its apparent usefulness as well (Table 4).
Less anticipated was the discovery that most survey respondents had no opinion about, no experience with, or no knowledge of most of the remainder of APSA programs. Our flagship publication, the American Political Science Review, drew both the strongest expressions of satisfaction and dissatisfaction, with dissatisfaction being conveyed by a majority of lapsed members and an almost even split between expressions of satisfaction and dissatisfaction among current members. This bifurcation over the Review posed and continues to pose a dilemma for anyone planning for the future of the Association.

The $A P S R$ is the leading publication in political science, as indicated by acceptance rates, the half-life of citations, and reputation. Moreover, survey respondents indicated their appreciation of the Review's rigor and of the book reviews in openended comments. The SPC, a diverse body, has come to the conclusion that the quality of the journal can be maintained and even enhanced if its breadth is widened, something current and past APSR editors have attempted despite difficulties. The SPC has asked the Council and APSA members to consider using newly available digital tools to overcome barriers.

Another impetus for establishing a planning committee was a notable decline in net revenue during a fouryear period when expenses increased more rapidly than income (see Table 3 ). These trends, coupled with a two-year drop in individual membership and a substantial decline in library memberships (Table 5 and Figure 1), gave the Council reason to worry that APSA budgets would soon be in the red. This year, the Annual Meeting Committee, led by Peter Lange, redressed the imbalance between Annual Meeting revenue and its share of support of Association activities by increasing Annual Meeting registration fees, reversing the negative revenue trend for the time being. In the spring, the Council agreed to a small increase in membership dues, which has further alleviated, though not fully resolved, the problem.

Longer-term trends of generational change, the changing environment in higher education, the possibilities offered by the Internet, and globalization of political science-as articulated in the APSA document, "Draft Design for a Strategic Planning Process" (www.apsanet.org/new/ planning/briefing.cfm)-present challenges but also offer exciting opportunities for our future. We have already used the web to increase our productivity and improve our service to members. Whether collecting information for the upcoming Centennial Biographical Directory of Members, making the Association's scholarly publications available through JSTOR, PROceedings, and PSonline, or creating opportunities for political scientists with E-Jobs, PSNonline, and the Annual Meeting proposal process, we are doing our best to take full advantage of the new media. We have also developed special sites for APSA members, undergraduate teachers, graduate students, civic educators, department chairs, those involved in service learning, and members of Organized Sections. Also, our site is now secure for financial transactions.

More is in the pipeline. By next year, for example, we hope to offer the Program Committee a webbased system to create the Annual Meeting panels. The Minority Identification Project will soon be entirely web-based. The SPC-and, earlier, the ad hoc Committee on Technology, led by Pippa Norris, and the Committee on Publications, chaired by Bert Rockman-have encouraged APSA's digital efforts, especially those using the web site. These committees have also recognized the high cost of information technology and its tendency to transform private goods into public ones. 


\section{APSA Membership}

1974 - 2000

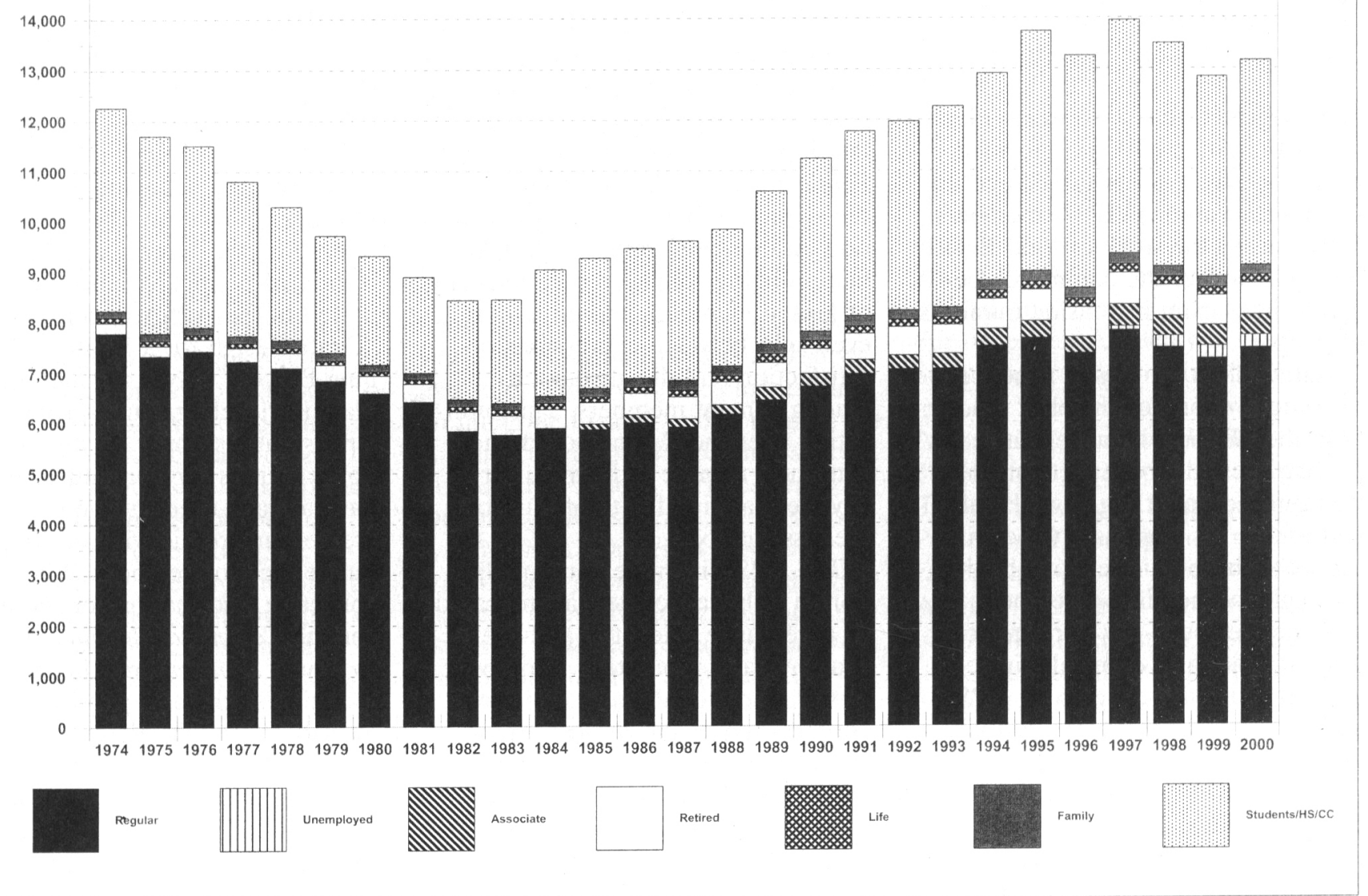

As a result, we are working to develop strategies for maintaining sufficient incentives for political scientists to continue their membership in the Association, even in the face of rising costs and open access to APSA resources.

While strategic planning consumed much energy this year, many other significant activities were undertaken. Peter Gourevitch led the search committee for candidates to serve as APSR editor upon Ada Finifter's completion of her second term in August 2001. The committee's task was complicated by the fact that the SPC was discussing the future of the APSR, creating some uncertainty among candidates as to what their roles and responsibilities would be as editor. Fortunately, communication between the SPC and the search committee helped
TABLE 1

Market Value of APSA Funds, 1987-00

\begin{tabular}{lcc}
\hline Year* $^{*}$ & $\begin{array}{c}\text { Trust and Development } \\
\text { and Centennial } \\
\text { Campaign Funds }\end{array}$ & $\begin{array}{c}\text { Congressional Fellowship } \\
\text { and Endowed } \\
\text { Awards Funds }\end{array}$ \\
\hline 1987 & $1,811,794$ & 362,174 \\
1988 & $1,685,345$ & 382,268 \\
1989 & $1,643,552$ & 394,837 \\
1990 & $1,630,718$ & 419,021 \\
$1991+$ & $1,555,574$ & $5,452,252$ \\
1992 & $1,905,090$ & $6,188,105$ \\
1993 & $2,118,787$ & $6,847,760$ \\
1994 & $2,190,976$ & $7,218,462$ \\
1995 & $2,807,182$ & $7,774,290$ \\
1996 & $3,248,013$ & $9,442,658$ \\
1997 & $4,283,425$ & $10,624,573$ \\
1998 & $5,965,087$ & $12,656,326$ \\
1999 & $6,984,978$ & $14,166,705$ \\
2000 (projected) & $7,791,720$ & $16,154,430$ \\
\hline
\end{tabular}

*June 30 of each year.

†Figures for 1991-93 were restated to reflect a change in accounting practice. 
TABLE 2

Organized Section

Members, 1999

\begin{tabular}{|c|c|c|}
\hline & Organized Section & $\begin{array}{l}\text { Number } \\
\text { of } \\
\text { Members }^{*}\end{array}$ \\
\hline 1 & $\begin{array}{l}\text { Federalism and } \\
\text { Intergovernmental } \\
\text { Relations }\end{array}$ & 412 \\
\hline 2 & Law and Courts & 802 \\
\hline 3 & Legislative Studies & 639 \\
\hline 4 & Public Policy & 833 \\
\hline 5 & $\begin{array}{l}\text { Political Organizations } \\
\text { and Parties }\end{array}$ & 574 \\
\hline 6 & Public Administration & 587 \\
\hline 7 & Conflict Processes & 342 \\
\hline 8 & $\begin{array}{l}\text { Representation and } \\
\text { Electoral Systems }\end{array}$ & 359 \\
\hline 9 & Presidency Research & 416 \\
\hline 10 & Political Methodology & 845 \\
\hline 11 & Religion and Politics & 496 \\
\hline 13 & Urban Politics & 410 \\
\hline 15 & $\begin{array}{l}\text { Science, Technology, } \\
\text { and Environmental } \\
\text { Policy }\end{array}$ & 326 \\
\hline 16 & Women and Politics & 629 \\
\hline 17 & $\begin{array}{l}\text { Foundations of Political } \\
\text { Theory }\end{array}$ & 632 \\
\hline 18 & $\begin{array}{l}\text { Information Technology } \\
\text { and Politics }\end{array}$ & 241 \\
\hline 19 & $\begin{array}{l}\text { International Security } \\
\text { and Arms Control }\end{array}$ & 490 \\
\hline 20 & Comparative Politics & 1544 \\
\hline 21 & $\begin{array}{l}\text { Politics and Society in } \\
\text { Western Europe }\end{array}$ & 399 \\
\hline 22 & State Politics and Policy & 427 \\
\hline 23 & Political Communication & 405 \\
\hline 24 & Politics and History & 686 \\
\hline 25 & Political Economy & 639 \\
\hline 26 & $\begin{array}{l}\text { Transformational } \\
\text { Politics }\end{array}$ & 220 \\
\hline 27 & New Political Science & 309 \\
\hline 28 & Political Psychology & 364 \\
\hline 29 & $\begin{array}{l}\text { Undergraduate } \\
\text { Education }\end{array}$ & 351 \\
\hline 30 & Politics and Literature & 271 \\
\hline 31 & Foreign Policy & 366 \\
\hline 32 & $\begin{array}{l}\text { Elections, Public } \\
\text { Opinion, and Voting } \\
\text { Behavior }\end{array}$ & 729 \\
\hline 33 & $\begin{array}{l}\text { Race, Ethnicity \& } \\
\text { Politics }\end{array}$ & 489 \\
\hline 34 & $\begin{array}{l}\text { Interdisciplinary History } \\
\text { \& Politics }\end{array}$ & \\
\hline
\end{tabular}

TABLE 3

Operating Budget Summary, FY 1986-00

\begin{tabular}{cccr}
\hline Year & Income & Expenditures & Surplus \\
\hline $1985-86$ & $1,505,224$ & $1,453,248$ & 51,976 \\
$1986-87$ & $1,585,000$ & $1,500,000$ & 85,307 \\
$1987-88$ & $1,637,637$ & $1,563,252$ & 74,385 \\
$1988-89$ & $1,847,151$ & $1,731,248$ & 115,903 \\
$1989-90$ & $1,891,773$ & $1,871,302$ & 20,471 \\
$1990-91$ & $2,158,118$ & $2,133,524$ & 24,594 \\
$1991-92$ & $2,256,647$ & $2,199,632$ & 74,804 \\
$1992-93$ & $2,290,313$ & $2,202,419$ & 87,894 \\
$1993-94$ & $2,574,436$ & $2,294,128$ & 280,308 \\
$1994-95$ & $2,734,375$ & $2,524,663$ & 209,712 \\
$1995-96$ & $2,822,154$ & $2,590,227$ & 231,927 \\
$1996-97$ & $2,979,845$ & $2,793,237$ & 186,607 \\
$1997-98$ & $3,068,237$ & $2,981,914$ & 86,323 \\
$1998-99$ & $3,150,001$ & $3,086,546$ & 63,455 \\
$1999-00^{*}$ & $3,325,000$ & $3,225,000$ & 100,000 \\
\hline
\end{tabular}

*Projected.

minimize this problem. The SPC understands the need for the next editor to be directly involved in discussions concerning proposed changes to the Review during the coming year. All concerned are committed to ensuring that the $A P S R$ continues to publish the best research in all areas of the discipline.

\section{Addressing Workforce Issues}

The SPC is also working, along with Charles Johnson's Committee on Education and Professional Development and the national office, to meet the needs of graduate students and junior faculty as they enter and try to advance in the changing academic workplace. The education committee prepared a report to the Council and all members of the Association regarding how to address problems facing new cohorts, noting that "The production of Ph.D.s in political science, the job markets for individuals holding doctorates in political science, the placement of those holding those degrees, and the conditions of employment for those degree holders must be core concerns for the American Political Science Association." The full text of the committee's report, including specific, significant recommendations and an invitation for comments, can be found at www.apsanet.org/about/ chairs/responsibilities.cfm. Participants in the Conference of Department Chairs at the Annual Meeting in Washington, DC, will consider the recommendations in the report. Final recommendations will be presented to the Council at its spring 2001 meeting.

The Committee on Education, in conjunction with the Departmental Services Committee, led by Ron Peters, has also completed and made available "Career Encounters: Political Science." This inspiring 25minute video, which is meant to encourage undergraduates to major in political science, features political science majors in a variety of inviting careers and at different stages of their professional lives. The video can be ordered online (www. apsanet.org/pubs/careervideo.cfm) and is one component of the two committees' program to build resources that departments and faculty can use on their campuses.

Paralleling the education committee's work has been APSA's participation in the formation of the Coalition on the Academic Workforce (CAW). Composed of over a dozen scholarly societies, CAW was formed to address the increasing use of part-time and full-time, nontenuretrack faculty by colleges and universities. This practice shortchanges new Ph.D.s in particular and can have a deleterious impact on educa- 


\begin{tabular}{ll} 
TABLE 4 & \\
Annual Meeting \\
Registration, 1968-98 \\
\hline 1968 & 3723 (Washington, DC) \\
1969 & 4142 (New York) \\
1970 & 2397 (Los Angeles) \\
1971 & 2732 (Chicago) \\
1972 & 3380 (Washington, DC) \\
1973 & 2312 (New Orleans) \\
1974 & 2773 (Chicago) \\
1975 & 2478 (San Francisco) \\
1976 & 2295 (Chicago) \\
1977 & 2624 (Washington, DC) \\
1978 & 2373 (New York) \\
1979 & 2687 (Washington, DC) \\
1980 & 2745 (Washington, DC) \\
1981 & 2887 (New York) \\
1982 & 2205 (Denver) \\
1983 & 2859 (Chicago) \\
1984 & 3391 (Washington, DC) \\
1985 & 2842 (New Orleans) \\
1986 & 3602 (Washington, DC) \\
1987 & 3524 (Chicago) \\
1988 & 4161 (Washington, DC) \\
1989 & 3496 (Atlanta) \\
1990 & 4505 (San Francisco) \\
1991 & 5179 (Washington, DC) \\
1992 & 4998 (Chicago) \\
1993 & 5635 (Washington, DC) \\
1994 & 5902 (New York) \\
1995 & 5559 (Chicago) \\
1996 & 6055 (San Francisco) \\
1997 & 6391 (Washington, DC) \\
1998 & 6633 (Boston) \\
1999 & 5818 (Atlanta) \\
\hline & \\
\hline
\end{tabular}

tional quality. For a copy of the report that led to the creation of the CAW, see www.apsanet.org/PS/ adjunct.

In a related development, APSA is increasing the listing of nonfaculty positions-both in and out of higher education-that might be of interest to holders of M.A. and Ph.D. degrees in the Personnel Service Newsletter. President-Elect Robert Jervis has a special interest in academic workforce issues and will undoubtedly encourage further placement and professional development efforts during his presidency.

Over the past three decades, the composition of the academic workforce has been as important to APSA as has placement and advancement within it. Through the Minority Fellows Program, the Minority Identification Project, and the
Ralph Bunche Summer Institute, progress has been made in diversifying the political science community. A survey conducted by APSA this spring shows that an impressive 71 APSA Minority Fellows now hold Ph.D.s in political science and scores of others hold master's degrees or are currently enrolled in graduate school. Moreover, in time for the fall round of the Minority Identification Project, participating departments will be able to exchange the names of promising students of color who have expressed interest in graduate study via a dedicated web site.

This year, the Ralph Bunche Summer Institute (RBSI), which attracts and prepares students for graduate school, hosted 13 African Americans, as the Institute was originally founded to do, and also 6 Latinos and a Pacific Islander-to the benefit of all concerned. The students uniformly agreed that the diversity of participants led to greater insights into minority politics. The students enjoyed working together and expressed appreciation for the opportunity that Director Paula McClain and her colleagues at UVA and APSA provided them. Eleven of the Bunche students have been selected to present their research at a poster session at the Annual Meeting.

Next year, RBSI moves to Duke University, which has pledged substantial support, under Professor McClain's leadership. We are grateful to everyone at UVA, not only in the department of government and foreign affairs and its chair Jeffrey Legro, but also throughout that institution, beginning with President John Casteen, for their dedication and significant contributions to the Institute. The National Science Foundation also deserves recognition for providing major ongoing funding of this important effort.

Much of the credit for the past and likely future success of APSA's minority programs goes to Maurice Woodard, who is retiring after reaching his 25th year at APSA. The profession is greatly indebted to him, as am I. He has promised that he will stay actively involved in the affairs of APSA, and I plan to hold him to that pledge.

\section{Broadening Our Reach}

Even as APSA is working to broaden the composition of the workforce in political science, we are also striving to widen our welcome to political scientists here and abroad. Three years ago, Council member David Laitin suggested the formation of a group of representatives from each of the area studies organizations, which could serve as a source of expertise for the Association. The result is the Area Studies Liaison Group, which meets regularly at APSA and has recommended creation of a new Organized Section on Comparative Democratization and agreed to sponsor several events at the Annual Meeting.

Among its sponsored programs is a two-day Library of Congress open house on Thursday, August 31, and Friday, September 1. Meeting registrants can tour the area studies rooms at the Library and receive an introduction to the institution's vast array of resources. Two in-depth orientation sessions will also be held for those wishing to learn how to access the collections there. The Liaison Group is also sponsoring a headliner panel on the contributions of area studies to the discipline and has worked with Program Chairs Ira Katznelson and Helen Milner-who will also edit the next volume of The State of the Discipline-to enhance participation by comparativists and international relations specialists working in underrepresented regions. The group has helped identify candidates for special Annual Meeting lectures and is seeking ways to promote internationalization of the Association. For more information on the work of the Liaison Group, go to www.apsanet.org/about/ international/areastudies.cfm.

One other area of APSA's work this year, representation of political science in Washington, deserves highlighting. In 1998, President Matthew Holden appointed an ad hoc Committee on Political Science and the National Science Foundation, led by Frank Sorauf. (See www. apsanet.org/new/nsf/nsfreport.cfm for 
TABLE 5

APSA Members 1974-2000

\begin{tabular}{|c|c|c|c|c|c|c|c|c|c|c|}
\hline Year & Regular & Unemployed & Associate & Retired & Life & Family & Student & $\begin{array}{c}\text { Total } \\
\text { Individual }\end{array}$ & $\begin{array}{c}\text { Total } \\
\text { Institutional }\end{array}$ & $\begin{array}{c}\text { TOTAL } \\
\text { MEMBERS }\end{array}$ \\
\hline 1974 & 7,793 & & & 217 & 101 & 137 & 4,006 & 12,254 & 3,504 & 15,758 \\
\hline 1975 & 7,335 & & & 206 & 100 & 149 & 3,912 & 11,702 & 3,648 & 15,350 \\
\hline 1976 & 7,428 & & & 245 & 96 & 134 & 3,603 & 11,506 & 3,588 & 15,094 \\
\hline 1977 & 7,228 & & & 270 & 95 & 142 & 3,076 & 10,811 & 3,466 & 14,277 \\
\hline 1978 & 7,094 & & & 301 & 97 & 154 & 2,655 & 10,301 & 3,338 & 13,639 \\
\hline 1979 & 6,845 & & & 310 & 91 & 148 & 2,335 & 9,729 & 3,339 & 13,068 \\
\hline 1980 & 6,592 & & & 344 & 91 & 135 & 2,159 & 9,321 & 3,337 & 12,658 \\
\hline 1981 & 6,423 & & & 349 & 92 & 129 & 1,901 & 8,894 & 3,283 & 12,177 \\
\hline 1982 & 5,838 & & & 388 & 97 & 134 & 1,984 & 8,441 & 3,156 & 11,597 \\
\hline 1983 & 5,764 & & & 382 & 104 & 130 & 2,068 & 8,448 & 3,018 & 11,466 \\
\hline 1984 & 5,891 & & & 378 & 111 & 151 & 2,511 & 9,042 & 3,059 & 12,101 \\
\hline 1985 & 5,879 & & 106 & 411 & 116 & 166 & 2,595 & 9,273 & 2,996 & 12,269 \\
\hline 1986 & 6,009 & & 145 & 432 & 117 & 173 & 2,589 & 9,465 & 3,046 & 12,511 \\
\hline 1987 & 5,913 & & 154 & 439 & 127 & 202 & 2,775 & 9,610 & 3,109 & 12,719 \\
\hline 1988 & 6,171 & & 173 & 450 & 129 & 186 & 2,728 & 9,837 & 2,975 & 12,812 \\
\hline 1989 & 6,445 & & 249 & 489 & 166 & 192 & 3,054 & 10,595 & 2,948 & 13,543 \\
\hline 1990 & 6,708 & & 258 & 488 & 163 & 180 & 3,436 & 11,233 & 3,004 & 14,237 \\
\hline 1991 & 6,967 & & 266 & 519 & 160 & 199 & 3,656 & 11,767 & 2,890 & 14,657 \\
\hline 1992 & 7,046 & & 279 & 557 & 159 & 182 & 3,740 & 11,963 & 3,057 & 15,020 \\
\hline 1993 & 7,061 & & 291 & 573 & 157 & 194 & 3,979 & 12,255 & 2,887 & 15,142 \\
\hline 1994 & 7,505 & & 343 & 593 & 159 & 195 & 4,121 & 12,916 & 2,908 & 15,824 \\
\hline 1995 & 7,654 & & 340 & 623 & 164 & 205 & 4,750 & 13,736 & 2,812 & 16,548 \\
\hline 1996 & 7,349 & & 323 & 596 & 168 & 210 & 4,618 & 13,264 & 2,841 & 16,105 \\
\hline 1997 & 7,808 & 82 & 429 & 625 & 167 & 218 & 4,611 & 13,940 & 2,706 & 16,646 \\
\hline 1998 & 7,464 & 226 & 400 & 607 & 165 & 206 & 4,428 & 13,496 & 2,653 & 16,149 \\
\hline 1999 & 7,247 & 248 & 412 & 590 & 163 & 191 & 3,981 & 12,832 & 2,550 & 15,382 \\
\hline 2000 & 7,454 & 247 & 415 & 617 & 164 & 196 & 4,065 & 13,158 & 2,475 & 15,633 \\
\hline
\end{tabular}

*As of January 15 each year.

a copy of the committee's report.) In conjunction with the committee's attempt to identify actions APSA could take to increase the appreciation of political science research at NSF, Authur Lupia organized a symposium in $P S$ on the public value of political science research that has been widely distributed throughout the Washington policy community and is available on our web site at www.apsanet.org/PS/march00/ politicalresearch.cfm.

At NSF itself, three promising developments have occurred. First, the distinguished social scientist Norman Bradburn, well versed in political science, has assumed the position of assistant director for Social, Behavioral and Economic Sciences (SBE). Second, NSF Director Rita Caldwell has announced that the twenty-first century is the "century of the social sciences." Third, NSF is planning a major initiative in the SBE that should substantially increase funding available in our fields. Perhaps the tide has turned.

On the humanities side of the house, this spring I was elected president of the National Humanities Alliance, whose primary function is to seek support for the National Endowment for the Humanities. Within the last two years, we have been able to reverse the assault on funding for the humanities and win a $\$ 5$ million increase. An equivalent increase in the coming fiscal year is possible.

\section{Shouldering Responsibility for APSA}

In the midst of reporting on the news at APSA, it is easy to take for granted the ongoing work of the Council, committees, and volunteers that constitutes our raison d'etre.
The attentive leadership of President Robert Keohane and the work of the Strategic Planning Committee, the APSR Editor Search Committee, the Committee on Education and Professional Development, the Committee on the Annual Meeting, the Departmental Services Committee, the Publications Committee, and the ad hoc Committees on Technology and on Political Science and the NSF have all been instrumental. However, many more individuals deserve to be mentioned by name. The March issue of $P S$, the December issue of the APSR, and our web site list the many reviewers, committee members, and representatives to other organizations who ably serve the political science community by contributing their time and judgment. The articles of $P S$, both in print and online, describe the efforts of people like Alberta 
Sbragia and John Garcia, who led the 1999 Annual Meeting Program Committee with such aplomb.

As you encounter the many contributors to the governance of the Association, please thank them for their efforts. Please also take note of the leaders of and the hundreds of financial contributors to APSA's Centennial Campaign, a remarkable testament to political scientists' con- cern for their discipline now and in the future.

Finally, I personally am grateful to the Association and its elected leaders for granting me a sixmonths' sabbatical this year, allowing me to accept a Bosch Foundation Public Policy Fellowship at the American Academy in Berlin and a visiting position at the Mount Vernon Campus of George Washington
University. This exhilarating experience was only possible thanks to the generosity of my colleagues in the national office who shouldered my assignments, especially Robert Hauck, who capably served as acting executive director in my stead. I am now back and look forward to continuing to hear from you about PSA's future and present.

July 13,2000
APSA Officers 1999-2000

\section{PRESIDENT}

Robert O. Keohane, Duke University

\section{PRESIDENT-ELECT}

Robert Jervis, Columbia University

VICE PRESIDENTS

Guillermo O'Donnell, University of Notre Dame

Virginia Sapiro, University of Wisconsin, Madison

Roberta S. Sigel, Rutgers University

\section{SECRETARY}

Fritz Scharpf, Max Planck Institute, Berlin

TREASURER

James Stimson, University of North Carolina, Chapel Hill

\section{EXECUTIVE DIRECTOR}

Catherine E. Rudder

PROGRAM CO-CHAIRS

Ira Katznelson, Columbia University

Helen Milner, Columbia University

EDITOR, APSR

Ada W. Finifter, Michigan State University

\section{COUNCIL}

1998-2000

George E. Marcus, Williams College

Luis Fraga, Stanford University

Cynthia McClintock, George Washington University

Eileen L. McDonagh, Northeastern University

Nancy E. McGlen, Niagara University

Howard J. Silver, Consortium of Social Science Associations

J. Ann Tickner, University of Southern California

\section{9-2001}

Randall Calvert, Washington University

William A. Galston, University of Maryland

Edmond J. Keller, University of California, Los Angeles

Gary King, Harvard University

Atul Kohli, Princeton University

David Rayside, University of Toronto

Christine M. Sierra, University of New Mexico

Sven Steinmo, University of Colorado, Boulder
Telephone

Numbers

$919 / 660-4322$

$212 / 854-4610$

$219 / 631-7756$

$608 / 263-2024$

$732 / 932-9283$

+4922127670

$919 / 962-0428$

202/483-2512

212/799-5975

$212 / 854-5138$

$517 / 339-4311$

$413 / 458-8045$

$650 / 723-5319$

202/994-6589

$617 / 373-4403$

$716 / 286-8059$

202/842-3525

$213 / 740-2266$
Email

Addresses

rkeohane@duke.edu

rlj1@columbia.edu

guillermo.a.odonnell.1@nd.edu sapiro@polisci.wisc.edu rsigel@aol.com

fwscharpf@compuserve.com

jstimson@email.unc.edu

rudder@apsanet.org

iik1@columbia.edu hvm1@columbia.edu

finifter@msu.edu

george.e.marcus@williams.edu fraga@stanford.edu mcclin@gwu.edu emcd@neu.edu nmcglen@niagara.edu silverhj@erols.com tickner@bcf.usc.edu

calvert@artsci.wustl.edu wg14@umail.umd.edu ekeller@ucla.edu king@harvard.edu kohli@princeton.edu david.rayside@utoronto.ca csierra@unm.edu steinmo@colorado.edu 
Nominating Committee

David Rohde, Michigan State University

Bert Rockman, University of Pittsburgh

Committee on International Political Science

James Gibson, Washington University

Committee on Education \& Professional Development

Charles Johnson, Texas A \& M University

Cheryl Miller, University of Maryland, Baltimore County

Committee on the Status of Latinos in the Profession Valerie Martinez-Ebers, Texas Christian University

Eloise Buker, Denison University

Committee on Endowments

John Mark Hansen, University of Chicago

Editorial Board, $P S$

Jeffrey Legro, University of Virginia

\section{CENTENNIAL CAMPAIGN}

\section{Co-Chairs}

Dale Rogers Marshall, Wheaton College

Jack Peltason, University of California

Executive Committee Co-Chairs

Frank Sorauf, University of Minnesota

Roger Davidson, University of Maryland, College Park

Presidents Council Co-Chairs

Lucius Barker, Stanford University

Elinor Ostrom, Indiana University
$517 / 355-7655$

$919 / 962-0428$

$405 / 325-2061$

$412 / 648-7287$

$314 / 367-1931$

$797 / 845-8833$

$207 / 581-1855$

215/898-6195

$410 / 455-2183$

$817 / 257-7395$

$740 / 587-6536$

$773 / 702-8051$

202/806-6722

804/924-3958

$508 / 285-8244$

714/824-3938

rohde@pilot.msu.edu

jstimson@email.unc.edu

rpeters@ou.edu

brockman+@pitt.edu

jgibson@artsci.wustl.edu

e339cj@polisci.tamu.edu

matt.moen@umit.maine.edu

rneuman@pobox.asc.upenn.edu

cmiller@umbc.edu

v.martinez@tcu.edu

buker@denison.edu

j-hansen@uchicago.edu

jmccormick@fac.howard.edu

jw14x@virginia.edu

612/624-5503

$301 / 405-4113$

415/723-0408

$812 / 855-3151$ dmarshall@wheatonma.edu newbean@aol.com

sorauf@polisci.umn.edu rdavidso@bss2.umd.edu

lucius@leland.stanford.edu ostrom@indiana.edu 
Finance Co-Chairs

Susan Bourque, Smith College

Loren Ross, Ceadarpoint Capital Management of New York

$413 / 585-3000$

212/308-9081

$614 / 292-2880$

$202 / 862-5893$

Congressional Fellowship Program Advisory Committee

Norman Ornstein, American Enterprise Institute for Public Policy

Minority Identification Project Steering Committee

Elliott Slotnick, Ohio State University

\section{APSA REPRESENTATIVES TO AFFILIATED ORGANIZATIONS}

American Association for the Advancement of Science (AAAS)-Section $\mathrm{K}$

Gary King, Harvard University

$617 / 495-2027$

$717 / 948-6049$

404/775-8495

202/686-5273

202/483-2512

$607 / 255-6205$

919/660-4303

202/483-2512

$617 / 495-3650$

202/496-1348

202/496-1348

202/496-1348 sbourque@sophia.smith.edu loren@cedarpointcapital.com

slotnick.1@osu.edu

nornstein@aei.org c4n@psu.edu

ronald.kahn@oberlin.edu

wilcoxc@erols.com rudder@apsanet.org

tjl7@cornell.edu pmcclain@duke.edu rudder@apsanet.org

sverba@harvard.edu

mkumar@towson.edu

mkumar@towson.edu

vdavis@ukcc.uky.edu

rhauck@apsanet.org

sdavis@apsanet.org smann@apsanet.org

jrichards@apsanet.org

Ityson@apsanet.org 